\title{
Qualitative and quantitative analysis of bacteria from vaginitis associated with intravaginal implants in ewes following estrus synchronization
}

\author{
Análise qualitativa e quantitativa de bactérias da vaginite associadas \\ com implante intravaginal em ovelhas após sincronização de estro
}

\author{
Carlos Otávio de Paula Vasconcelos ${ }^{I^{*}}$ Felipe Zandonadi Brandão ${ }^{\mathrm{I}}$ Gabriel Martins ${ }^{\mathrm{II}}$ \\ Bruno PennaII Joanna Maria Gonçalves de Souza-FabjanI ${ }^{I}$ Walter Lilenbaum ${ }^{I I}$
}

\section{ABSTRACT}

This study evaluated the presence of vaginitis and the bacterial load associated with different intravaginal implants in ewes. Twenty-four Dorper and crossbred ewes were allocated into three groups and received intravaginal implant containing $0.3 g$ progesterone (CIDR $\left.{ }^{\circledR}\right)$, 60mg MAP or sponges without progesterone (CONTROL) for six days. Then, CIDR and MAP treated-ewes received $12.5 \mathrm{mg}$ dinoprost and $3001 \mathrm{U}$ eCG. Vaginal mucus samples were collected at four times: before device insertion, at the day of its removal, 24 and 48 hours after. The samples were cultured and the colonies were counted (CFU) $m L)$ and identified. The results obtained from the counting of CFU $\mathrm{mL}^{-1}$ were submitted to Kruskal-Wallis $H$ test, with $P<0.05$ being considered significant. Before device insertion, $68.2 \%$ of the samples yielded Staphylococcus spp. and $60.0 \%$ of them were Staphylococcus aureus. After implant removal, 100\% of ewes had clinical signs of vaginitis. However, the level of local infection in the CONTROL-ewes was lower $(P>0.05)$ in comparison with MAP and CIDR-treated ewes. During the occurrence of vaginitis, the predominant isolates belonged to the coliform group, mainly Escherichia coli $(72.7 \%)$. Such infection was not determined by the members of the vaginal microbiota that were present before implant insertion and normal microbiota was restored between 24 to 48 hours after insert removal.

Key words: intravaginal device, microorganism, sheep, vaginal infection.

RESUMO

Este estudo avaliou a presença de vaginite e contagem bacteriana associada ao uso de diferentes dipositivos intravaginais em ovelhas. Vinte e quatro fêmeas Dorper e mestiças foram alocadas em três grupos e receberam implante intravaginal contendo $0,3 \mathrm{~g}$ de progesterona $\left(C I D R^{\circledR}\right), 60 m g$ de acetato de medroxiprogesterona (MAP) ou esponjas sem progesterona (CONTROLE) por seis dias.
Posteriormente, as ovelhas tratadas com CIDR e MAP receberam 12,5mg de dinoprost e 300 UI de eCG. Amostras do muco vaginal foram coletadas em quatro momentos: antes da inserção do dispositivo, no dia de sua retirada, 24 e 48 horas após. As amostras foram cultivadas $e$ as colonias foram contadas (UFC $\left.m L^{-1}\right) e$ identificadas. Os resultados obtidos da contagem das UFC $m L^{-1}$ foram submetidos ao teste do qui-quadrado, com $P<0,05$ sendo considerado significativo. Antes da inserção do dispositivo, $68,2 \%$ das amostras continham Staphylococcus spp., sendo 60,0\% delas Staphylococcus aureus. Após a remoção do implante, 100\% das ovelhas apresentaram sinais clínicos de vaginite. Entretanto, o grau de infecção local nas ovelhas do grupo CONTROLE foi menor $(P>0.05)$, em comparação com as ovelhas recebendo CIDR e MAP. Durante a ocorrência da vaginite, os isolados predominantes pertenciam ao grupo dos coliformes, principalmente Escherichia coli $(72,7 \%)$. Tal infecção não foi determinada pelos membros da microbiota vaginal, que estavam presentes antes da inserção dos dispositivos, e a microbiota normal foi reestabelecida entre 24 e 48 horas após sua remoção.

Palavras-chave: dispositivo intravaginal, microorganismo, ovelha, infecção vaginal.

\section{INTRODUCTION}

Sheep are well adapted to different environments and they are versatile as producers of food and raw material such as milk, meat and skin. Moreover, they represent a good model for the development of reproductive biotechnologies (TIBARY et al., 2005) and have a short productive cycle when compared to cattle. Thus, sheep production has recently become of considerable interest worldwide.

\footnotetext{
'Departamento de Patologia e Clínica Veterinária, Universidade Federal Fluminense (UFF), 24220-900, Niterói, RJ, Brasil. E-mail: cvasconcelos@vm.uff.br. "Corresponding author.

"Laboratório de Bacteriologia Veterinária, Universidade Federal Fluminense (UFF), Niterói, RJ, Brasil 
Considering the reproductive seasonality of ewes, intravaginal progestagen implants are frequently used for estrus induction or synchronization, which may allow better reproductive management planning and are crucial for timed artificial insemination (AMIRIDIS \& $\mathrm{CSEH}, 2012$ ). However, when the implant is removed, mucopurulent vaginal discharge and other clinical signs of vaginitis are commonly observed (PENNA et al., 2013), which could potentially lead to ascending uterine infections and result in decreased pregnancy rate.

The effect of hormones, as well as the mechanical presence of the devices, may predispose the sheep to purulent vaginitis (MANES et al., 2010; PENNA et al., 2013). This infection is often due to proliferation of the local microbiota and is typically characterized by erythema, a purulent vaginal discharge and abundant vaginal leukocytes (MANES et al., 2010). According to SUÁREZ et al. (2006), although the bacterial population increases temporarily, it returns to its normal values two days after sponge removal. The authors also hypothesized that the bacteria present at the moment the intravaginal sponge is inserted and its by-products could later promote further inflammation.

There are few studies in small ruminants regarding bacteriological evaluation (OLIVEIRA et al., 2013; PENNA et al., 2013). Additionally, there is a lack of literature about the effects of progestagenimpregnated sponges regarding the specific bacterial characterization in the vaginal microbiota. Moreover, the comparison between the effect of progestagen or natural progesterone-containing devices had not been performed until now. Therefore, the purpose of the current experiment was to conduct the qualitative and quantitative analysis of bacteria from vaginitis associated with the use of different intravaginal implants in ewes subjected to estrus synchronization.

\section{MATERIALS AND METHODS}

Animals

A total of 24 Santa Inês $(n=16)$ and Dorper/Santa Inês $(n=8)$ pluriparous ewes between 2 and 4 years old were studied. Before the beginning of the experiment, the ewes were subjected to a gynecological exam by transrectal ultrasound in order to evaluate the genital tract. Only animals without clinical disorders and showing body condition score of 2.5-3.5 (1-5 scale) were included (SUITER, 1994).

Study design

The animals were randomly distributed into three experimental groups and received an intravaginal implant with $0.3 \mathrm{~g}$ progesterone $(\mathrm{n}=8$, CIDR $^{\circledR}$, Pfizer Brazil Animal Health, São Paulo, Brazil), 60mg medroxyprogesterone acetate, MAP ( $\mathrm{n}=8$, Progespon ${ }^{\circledR}$, Syntex, Buenos Aires, Argentina) or sponges without progesterone $(n=8)$, as a control group. At the fifth day after the implants were inserted, animals from CIDR and MAP groups were injected with $12.5 \mathrm{mg}$ dinoprost tromethamine i.m. (Lutalyse ${ }^{\circledR}$, Pfizer Brazil Animal Health, São Paulo, Brazil) and 300 IU equine chorionic gonadotropin (eCG) i.m. (Novormon $^{\circledR}$, Syntex, Buenos Aires, Argentina), whereas the control group received $1.5 \mathrm{~mL}$ of saline solution i.m. All intravaginal devices remained in place for six days.

After sponge removal, estrus detection was done (using rams) twice daily. Ewes were considered to be in estrus when they allowed to be mounted. The rams were not allowed to achieve intromission.

\section{Bacteriology}

A sterile swab was used to collect samples from the posterior region of the vagina, after cleaning the vulva with $70^{\circ} \mathrm{GL}$ (Gay Lussac) alcohol at four different times: before the implant insertion, at its removal, and 24 and 48 hours after removal. Samples were transferred to the laboratory in transport culture medium (Stuart's medium, Copan, Italy).

The Spread-Plate colony counting technique was used for quantitative assessment (YESILMEN et al., 2008). After the quantification of CFU, data were sorted into three categories:

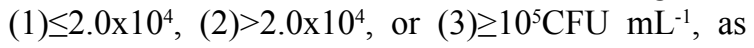
previously described by OLIVEIRA et al. (2013) for further comparison.

The swabs were vortexed in $1 \mathrm{~mL}$ sterile phosphate buffered saline, with $\mathrm{pH} 7.4$ for 1 minute, the suspension was serially diluted, bacteria were counted on Blood Agar plates (Merck, Darmstadt, Germany), and incubated for 48 hours at $37^{\circ} \mathrm{C}$. After the bacteria were counted, smears were made, Gramstained, and examined microscopically. Samples with morphology consistent with Gram-negative rods were transferred to EMB Teague Agar (Merck), whereas those suggestive of Staphylococcus spp. were transferred to Mannitol-salt-Agar (Merck) and incubated for 48 hours at $37^{\circ} \mathrm{C}$.

Bacteria were identified on the basis of colony characteristics, Gram stain, pigment production and biochemical reactions, including agar Triple Sugar Iron (TSI), citrate, urease, indol, Methyl Red (MR), Voges Proskauer (VP), nitrate and motility tests, catalase activity test, tube coagulase test, and aerobic fermentation of several carbohydrates. 
Bacteria were classified as described in previous studies (PENNA et al., 2013).

Statistical analysis

A completely randomized design was applied, with three experimental groups containing eight repetitions each one. The results obtained from the counting of colonies forming units $\left(\mathrm{CFU} \mathrm{mL} \mathrm{m}^{-1}\right)$ were sorted into three categories and compared by KruskalWallis $\mathrm{H}$ test for one-way ANOVA on ranks, followed by SNK post-test. A value of $P<0.05$ was considered to be statistically significant. Statistical analyses were performed using GraphPad Prism 5.0a software.

\section{RESULTS}

Two ewes, one from CIDR group and another from MAP group lost their implants during the experiment and were excluded from the analysis. Before device insertion, similar

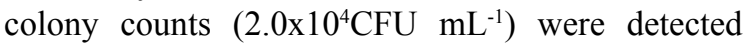
in all three treatment groups. Isolates with typical characteristics of Staphylococcus spp. (68.2\%) were obtained from 15 samples, five in each group. Out of these, Staphylococcus aureus was the most frequently observed species $(60 \% ; 9 / 15)$, followed by Staphylococcus epidermidis (40\%; 6/15). Seven ewes showed other bacterial genera growth.

All 22 ewes showed characteristic signs of vaginitis, such as mucopurulent discharge and local inflammation at the moment implants were removed.
Moreover, as shown in table 1 , all the animals showed an increase in CFU counting, being higher $(P<0.05)$ in MAP and CIDR groups $\left(\geq 10^{5} \mathrm{CFU} \mathrm{mL}^{-1}\right)$ than in

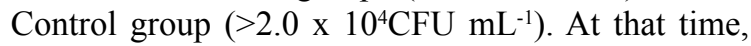
two animals were detected with Staphylococcus epidermidis $(9.1 \%$; 2/22), while 20 showed Gramnegative rods, identified as Escherichia coli $(72.7 \%$; 16/22) or Klebsiella pneumoniae (18.2\%; 4/22).

Counts were high $\left(\geq 10^{5} \mathrm{CFU} \mathrm{mL} \mathrm{mL}^{-1}\right)$ for all three groups studied at 24 and 48 hours after implant removal. With regard to the qualitative analysis, after 48 hours, the microbiota returned to be primarily of Staphylococcus genus, according to figure 1.

\section{DISCUSSION}

All the studied animals displayed vaginitis six days after the implants were inserted, with typical clinical signs such as mucopurulent discharge, erythemas and increased local sensitivity, besides a considerable increase in microbial load, independently of the type of implant and the presence of progesterone. Those outcomes corroborate previous data suggesting that the use of progestagen intravaginal implants in healthy ewes may become a vaginitis predisposing factor, but also demonstrate the effect of implant physical action per se (SUÁREZ et al., 2006; SARGISON et al., 2007; YESILMEN et al., 2008).

An unexpected finding concerns the microbial population dynamics. Although an increase in bacterial count after the insertion of implants has

Table 1 - Frequency distribution of the bacterial counts $\left(\mathrm{CFU} \mathrm{mL} \mathrm{mL}^{-1}\right)$ observed before intravaginal implant insertion, at its removal, and 24 and 48 hours after removal, and percentage of ewes in each scale of CFU mL ${ }^{-1}$ receiving CIDR, MAP or CONTROL (sponge without progesterone) devices for estrus synchronization.

\begin{tabular}{|c|c|c|c|c|}
\hline Time & $\mathrm{CFU} \mathrm{mL} \mathrm{m}^{-1}$ & CIDR & MAP & CONTROL \\
\hline \multirow{3}{*}{ Before } & $=2.0 \times 10^{4}$ & $50.0 \%(4 / 8)$ & $50.0 \%(4 / 8)$ & $62.5 \%(5 / 8)$ \\
\hline & $>2.0 \times 10^{4}$ & $50.0 \%(4 / 8)$ & $12.5 \%(1 / 8)$ & $37.5 \%(3 / 8)$ \\
\hline & $=10^{5}$ & $0.0 \%(0 / 8)$ & $37.5 \%(3 / 8)$ & $0.0 \%(0 / 8)$ \\
\hline \multirow{3}{*}{ Removal } & $=2.0 \times 10^{4}$ & $0.0 \%(0 / 7)$ & $0.0 \%(0 / 8)$ & $0.0 \%(0 / 7)$ \\
\hline & $>2.0 \times 10^{4}$ & $42.8 \%(3 / 7)$ & $0.0 \%(0 / 8)$ & $100.0 \%(7 / 7)$ \\
\hline & $=10^{5}$ & $57.1 \%(4 / 7)$ & $100.0 \%(8 / 8)$ & $0.0 \%(0 / 7)$ \\
\hline \multirow{3}{*}{$24 \mathrm{~h}$ after } & $=2.0 \times 10^{4}$ & $0.0 \%(0 / 7)$ & $0.0 \%(0 / 8)$ & $0.0 \%(0 / 7)$ \\
\hline & $>2.0 \times 10^{4}$ & $0.0 \%(0 / 7)$ & $12.5 \%(1 / 8)$ & $14.3 \%(1 / 7)$ \\
\hline & $=10^{5}$ & $100.0 \%(7 / 7)$ & $87.5 \%(7 / 8)$ & $85.7 \%(6 / 7)$ \\
\hline \multirow{3}{*}{$48 \mathrm{~h}$ after } & $=2.0 \times 10^{4}$ & $0.0 \%(0 / 7)$ & $0.0 \%(0 / 8)$ & $0.0 \%(0 / 7)$ \\
\hline & $>2.0 \times 10^{4}$ & $0.0 \%(0 / 7)$ & $0.0 \%(0 / 8)$ & $0.0 \%(0 / 7)$ \\
\hline & $=10^{5}$ & $100.0 \%(7 / 7)$ & $100.0 \%(8 / 8)$ & $100.0 \%(7 / 7)$ \\
\hline
\end{tabular}




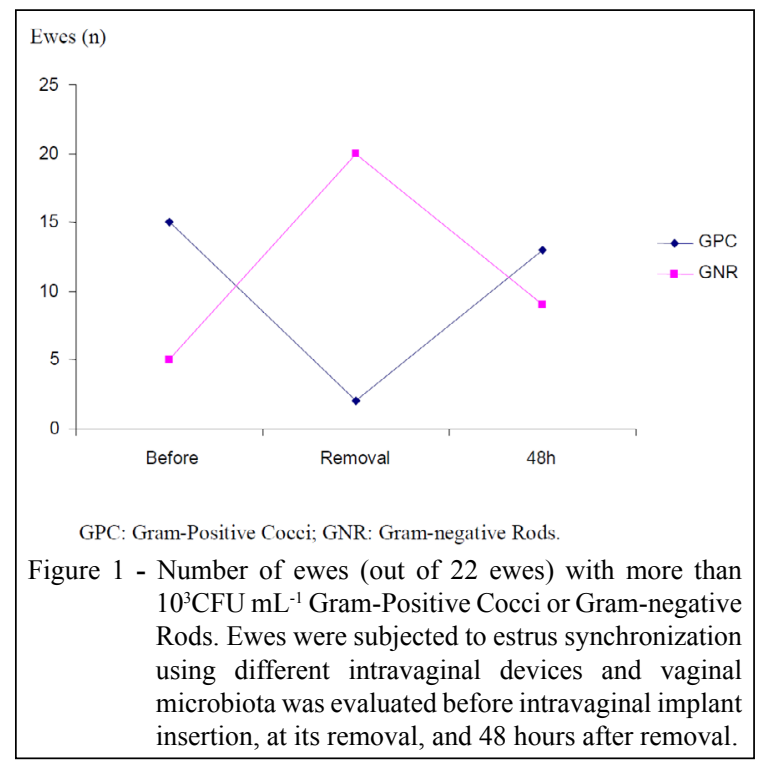

been reported (SUÁREZ et al., 2006; YESILMEN et al., 2008), in other studies the count decreases 24-48 hours after implant removal. SUÁREZ et al. (2006) have suggested that the predominant presence of polymorphonuclear leukocytes in the vagina of the sponge-treated ewes may contribute to the very fast clearance of the bacterial load observed after its removal. However, this was not observed in the present study, as the count remained high for all groups $\left(\geq 10^{5} \mathrm{CFU} \mathrm{mL} \mathrm{mL}^{-1}\right)$ even 48 hours after the implants were removed.

Curiously, the microorganisms responsible for the vaginitis were not those that were prevalent in the normal microbiota that prevailed before the insertion of the intravaginal devices (Staphylococcus spp.). Instead, bacteria from the coliform group, probably of fecal source, were predominant when clinical vaginitis was present. These findings indicate that, besides the quantitative increase of the vaginal microbiota after the use of intravaginal implants, an important qualitative switch also took place. These data contradict the hypothesis of SUÁREZ et al. (2006), in which the bacteria present at the time of intravaginal sponge insertion could promote further inflammation. Although other study (YESILMEN et al., 2008) reported qualitative changes of the bacterial load, specific identification of the agents has not been conducted. Escherichia coli has been reported as an opportunistic agent of bacterial vaginitis, not only in ewes (SARGISON et al., 2007; MARTINS et al., 2009), but also in other ruminants (PADULA \& MACMILLAN, 2006; SHELDON et al., 2008; OLIVEIRA et al., 2013). Nevertheless, the mechanism by which the original population of Staphylococci, represented predominantly by the well-known opportunistic bacteria $\boldsymbol{S}$. aureus, was replaced by coliforms as agents of the vaginitis remains unclear.

It is proposed that the presence of vaginal implants may have altered the vaginal environment. Intravaginal sponges themselves have been shown to generate an inflammatory response, with the accumulation of vaginal fluid and a concomitant increase in bacterial microbiota (MOTLOMELO et al., 2002; SUÁREZ et al., 2006). Additionally, the presence of progestagen is thought to lead to a compromise of the immune function in the female reproductive tract (LEWIS, 1997; LEWIS, 2003; SEALS et al., 2003). A short exposure to the luteal or exogenous progesterone jeopardizes the immunological functions in the reproductive tract, which in some animals, including ewes, makes the uterus more susceptible to infections (LEWIS, 2003; SEALS et al., 2003). Nevertheless, the control animals, which used intravaginal sponges without progestagen, also developed vaginitis, showing that the action of the hormone may be not the only triggering factor of the infection, as suggested by YESILMEN et al. (2008). Thus, the evidence suggests that physical action of the implant device would be able to cause inflammatory reactions independent of hormones and of modifying the vaginal environment (SUÁREZ et al., 2006; YESILMEN et al., 2008). Moreover, the presence of implants may also facilitate the invasion and adherence of Gram-negative rods of fecal origin. However, it is noteworthy that despite vaginitis was present, CFU analysis of the control group was lower than that of the two treatment groups. Indeed, ewes receiving MAP and CIDR devices had similar CFU, suggesting that medroxiprogesterone acetate may promote an equal local inflammatory reaction to natural progesterone. When applying this technique under field conditions, the use of dry cleaning in perianal region and a reduction in the length of device string are recommended. These modifications in the standard procedure may minimize fecal contamination at device insertion.

\section{CONCLUSION}

Even though all ewes demonstrated vaginitis after implant removal, CFU analysis of the control group was lower than MAP and CIDR-treated ewes. This suggests that, besides the physical action, hormones may also interfere on the bacterial load, regardless of their origin (synthetic or natural). The agents of the vaginitis were coliforms, which were 
replaced by the original microbiota 48 hours after implant was removed.

\section{ACKNOWLEDGEMENTS}

The authors thank the staff of Universidade Federal Fluminense (UFF) for technical assistance. WL and FZB are fellows of the Conselho Nacional de Desenvolvimento Científico e Tecnológico (CNPq)

\section{REFERENCES}

AMIRIDIS, G.S.; CSEH, S. Assisted reproductive technologies in the reproductive management of small ruminants. Animal Reproduction Science, v.130, p.152-161, 2012. Available from: <http://www sciencedirect.com/science/article/pii/S0378432012000358>. Accessed: Nov. 11, 2014. doi: 10. 10.1016/j.anireprosci.2012.01.009.

LEWIS, G.S. Uterine health and disorders. Journal of Dairy Science, v.80, p.984-994, 1997. Available from: $<\mathrm{http}: / /$ www.sciencedirect. com/science/article/pii/S0022030297760247>. Accessed: Dec. 05, 2014. doi: 10.3168/jds.S0022-0302(97)76024-7.

LEWIS, G.S. Role of ovarian progesterone and potential role of prostaglandin F2 $\alpha$ e prostaglandin E2 in modulating the uterine response to infectious bacteria in postpartum ewes. Journal of Animal Science, v.81, p.285-293, 2003. Available from: $<$ http:/www. animalsciencepublications.org/.../1/285>. Accessed: Jan. 04, 2015.

MANES, J. et al. Changes in the aerobic vaginal flora after treatment with different intravaginal devices in ewes. Small Ruminant Research, v.94, p.201-204, 2010. Available from: <http:/www. sciencedirect.com/science/article/pii/S0921448810002221>. Accessed: Jan. 13, 2015. doi: 10.1016/j.smallrumres.2010.07.021

MARTINS, G. et al. Prevalence and antimicrobial susceptibility of vaginal bacteria from ewes treated whit progestin-impregnated intravaginal sponges. Small Ruminant Research, v.81, p.182184, 2009. Available from: <http://www.sciencedirect.com/ science/article/pii/S0921448808002484>. Accessed: Jan. 21, 2015. doi: 10.1016/j.smallrumres.2008.12.003.

MOTLOMELO, K.C. et al. Synchronization of estrus in goats: the use of different progestagen treatments. Small Ruminant Research, v.45, p.45-49, 2002. Available from: <http://www. sciencedirect.com/science/article/pii/S092144880200113X>. Accessed: Feb. 03, 2015. doi: 10.1016/S0921-4488(02)00113-X.

OLIVEIRA, J.K. et al. Changes in the vaginal flora of goats following a short-term protocol of oestrus induction and synchronisation with intravaginal sponges as well as their antimicrobial sensitivity. Small Ruminant Research, v.113, p.162-166, 2013. Available from: $<$ http://www.sciencedirect.com/ science/article/pii/S0921448813000813>. Accessed: Feb. 03, 2015. doi: 10.1016/j.smallrumres.2013.02.011
PADULA, A.M.; MACMILLAN, K.L. Effect of treatment with two intravaginal inserts on the uterine and vaginal microflora of early postpartum beef cows. Australian Veterinary Journal, v.84, p.204-208, 2006. Available from: <http://www.ncbi.nlm.nih. gov/pubmed/16821488>. Accessed: Dec. 18, 2014.

PENNA, B. et al. Progestin-impregnated intravaginal sponges for estrus induction and synchronization influences on goats vaginal flora and antimicrobial susceptibility. Animal Reproduction Science, v.142, p.71-74, 2013. Available from: <http://www.sciencedirect.com/science/ article/pii/S0378432013002704>. Accessed: Feb. 15, 2015 doi: 10.1016/j.anireprosci.2013.09.006.

SARGISON, N.D. et al. Shiga toxin-producing Escherichia coli as a perennial cause of abortion in a closed flock of Suffolk ewes. Veterinary Record, v.160, p.875-876, 2007. Available from: <http://www.ncbi.nlm.nih.gov/ pubmed/17586793>. Accessed: Feb. 15, 2015

SEALS, R.C. et al. Uterine response to infectious bacteria in estrous cyclic ewes. American Journal of Reproductive Immunology, v.49, p.269-278, 2003. Available from: $<$ http://onlinelibrary.wiley. $\mathrm{com} /$ doi/10.1034/j.1600-0897.2003.00039.x/abstract;jsessionid= 65DED6E1E45D24018E895130BF85E45A.f04t01>. Accessed: Nov. 27, 2014. doi: 10.1034/j.1600-0897.2003.00039.x

SHELDON, I.M. et al. Uterine diseases in cattle after parturition. Veterinary Journal, v.176, p.115-121, 2008. Available from: <http://onlinelibrary.wiley.com/doi/10.1034/ j.1600-0897.2003.00039.x/abstract>. Accessed: Jan. 27, 2015. doi: 10.1016/j.tvj1.2007.12.031.

SUÁREZ, G. et al. Changes in the aerobic vaginal bacterial mucous load and assessment of the susceptibility to antibiotics after treatment with intravaginal sponges in anestrous ewes. Small Ruminant Research, v.63, p.3943, 2006. Available from: <http://www.sciencedirect.com/ science/article/pii/S0921448805000386>. Accessed: Nov. 21, 2014. doi: 10.1016/j.smallrumres.2005.01.011.

SUITER, J. Body condition scoring in sheep and goats. Farmnonte 69/94, 1994. Available from: <http://www.agric.wa.gov.au/content/ aap/sl/m/fn069 1994.htm>. Accessed: Nov. 21, 2014.

TIBARY, A. et al. Update on reproductive biotechnologies in small ruminants and camelids. Theriogenology, v.164, p.618-638, 2005. Available from: <http://www.sciencedirect.com/science/ article/pii/S0093691X05001779>. Accessed: Jan. 25, 2015. doi: 10.1016/j.theriogenology.2005.05.016.

YESILMEN, S. et al. The effect of progestagen on the changes of the vaginal flora arising from intravaginal sponge treatment and susceptibility of the vaginal flora to antibiotics in ewes. Journal of Animal and Veterinary Advances, v.7, p.1418-1421, 2008. Available from: <http://docsdrive.com/pdfs/medwelljournals/ javaa/2008/1418-1421.pdf>. Accessed: Dec. 12, 2014. 